\title{
Artikel
}

Robert Wiśniewski*

\section{How Numerous and How Busy were Late-Antique Presbyters?}

https://doi.org/10.1515/zac-2021-0011

\begin{abstract}
This article seeks to count late-antique clergy and assess their workload. It estimates the number of clerics, and particularly presbyters, in Christian communities of various sizes, and investigates how and why the ratio of clerics to laypersons changed over time. First, by examining the situation in the city of Rome, it demonstrates that the growth in the ranks of the presbyters from the third to the fifth century was slow, and argues that this resulted from the competing interests of the bishops, lay congregation, rich donors, and above all the middle clergy. It is the last group who were reluctant to raise their number as this had a negative impact on their income. The results of this phenomenon can also be seen in other big sees of Christendom, in which, in Late Antiquity, there was one presbyter per several thousand laypersons. Interestingly, in smaller towns, this ratio was significantly lower, and in the countryside, it remained in the lower hundreds. Second, this article shows how the changing ratio of clerics to laypersons affected the level of professionalization of the former. In the big cities, the ecclesiastical duties of presbyters who served in a growing community were getting heavier. This turned the presbyters into full-time religious ministers, at the same time making them even more dependent on ecclesiastical income. In the towns and villages, however, the pattern was different. In the places in which one presbyter served a very small community, his job was less time-consuming but also brought him less income. In consequence, rural presbyters had to support their families through craft work, commerce, or farming, and they had time for this.
\end{abstract}

Keywords: Late Antiquity, Ancient Christianity, Clergy, Rome

*Corresponding Author: Robert Wiśniewski, Faculty of History, University of Warsaw, Krakowskie Przedmieście 26/28, 00-927 Warszawa, Poland; e-mail: r.wisniewski@uw.edu.pl 
Several scholars have already tried to quantify the late-antique clergy. ${ }^{1}$ In the last decade, Raymond Van Dam estimated the possible number of clerics ca. 400 as around 100,000, on average 50 in each of 2,000 bishoprics of the Roman world. ${ }^{2}$ More recently, Ian Wood, having added some new evidence, particularly from the sixth and seventh centuries, ended up with the same number as Van Dam, 100,000 clerics, but not in the same period; he estimated that this number was reached only two centuries later, ca. $600 .^{3}$ In this article, I try to count clerics once again. I will show some new evidence that has not been discussed so far in this context, but also my purpose is different from that of Van Dam and Wood. They both were primarily interested in the impact which the numerous clergy and monks had on the function of the state and the economic life of the Roman empire, or what was left of it. In this they followed A. H. M. Jones' observations, focused on how much this huge army of "for the most part idle mouths" had weighed on the limited resources of the empire, and to some extent Edward Gibbon's remarks on 1,800 bishops preaching to the inhabitants of the Roman world. ${ }^{4}$ My interest lies in the every-day function of the church rather than the state, and more particularly in the level of professionalization of clerics.

The process of their professionalization started already in the third century, but it did not run equally smoothly in all regions of Christendom. ${ }^{5}$ Its pace very much depended on the income which the ecclesiastical office-holders received thanks to their church activities and on the time which they had to spend while exercising them. Thus, in order to answer the question of whether late-antique bishops, presbyters, and deacons were full or part-time clerics we have to learn how much they earned and how busy they were. And both of these questions demand assessment of how numerous the clerics were in relation to lay Christians in their communities. This ratio obviously varied from place to place, and so, unlike Van Dam and Wood, I will not seek to assess the numbers of clerics

1 The work on this article was sponsored by the National Science Centre (Poland, grant 2013/10/E/HS3/00202).

2 Raymond Van Dam, "Bishops and Clerics during the Fourth Century: Numbers and Their Implications," in Episcopal Elections in Late Antiquity (ed. Johan Leemans et al.; Berlin: De Gruyter, 2011), (217-242) 226.

3 Ian Wood, The Transformation of the Roman West (Leeds: ARC Humanities, 2018), 57-63.

4 Arnold H. M. Jones, The Later Roman Empire 284-302. A Social Economic and Administrative Survey 2 (Oxford: Blackwell, 1964), 933, quoted by Van Dam, "Bishops and Cleric” (see note 2), 226; Edward Gibbon, The History of the Decline and Fall of the Roman Empire 6 (New York: Fred de Fau \& Company Publishers, 1906), 291, chapter 38, quoted by Wood, The Transformation (see note 3), 57.

5 Georg Schöllgen, Die Anfänge der Professionalisierung des Klerus und das Kirchliche Amt in der Syrischen Didaskalie (JbAC.E 26; Münster: Aschendorff, 1998). 
globally, but instead to look at specific cities, towns, and villages. My focus will be on the presbyters. They made a group whose visibility in our evidence is much lower than that of the bishops and whose duties in several aspects differed from those of the latter. Nevertheless, from the end of the fourth century on, especially with the emergence of the network of local churches within the same diocese, the presbyters were slowly becoming a front line of the church. These were the clerics that most people had a chance to meet on a daily basis and who had liturgical power meeting almost all needs of the Christian people: they could baptise, celebrate the Eucharist, preach, anoint the sick, administer penance, and, if asked, bless a marriage and bury the dead. If we want to know whether the ritual needs of a community were satisfied, we do not need to ask how numerous the bishops were, as in most places they could not possibly do everything necessary in this respect by themselves; neither do we need to enquire how numerous the lower clerics were, as they were not essential for the cult-the role of janitors or fossores could be taken by laypeople. But we do need to know how numerous the presbyters were, and this article seeks to answer this question. ${ }^{6}$

Obviously, the ratio of the lay Christians to presbyters did not affect all spheres of clerical life. It did not have much impact on the time spent on preparing a sermon, celebrating the Eucharist, or dealing with necessary repairs in church buildings: whether 100 or 500 people attended the Mass, the job was quite similar. But this ratio was essential for the time spent on visiting the sick, administering penance, performing any sort of individual blessings at home of the faithful, assisting at funerals, and blessing marriages.

Needless to say, the assessment of this ratio is very difficult. First of all, our sources very rarely give us a number of the presbyters in a specific place. And this concerns even those cities from which we have very good evidence focused on the church and its clergy. A good example is Tours during the episcopacy of Gregory (573-594), whose prolific writings attest to about a dozen presbyters in this city, but their exact number is impossible to assess because some of them are anonymous and we cannot say if different stories tell about the same or different clerics, or whether others held their office at the same time, and whether still others were simply never mentioned. Other places have quite good epigraphic evidence. Sabine Hübner has collected and studied burial inscriptions from the city of Korykos and the town of Korasion in Cilicia: a bishop, 23 presbyters, 31 deacons,

6 For the role of the minor orders in general see Bernhard Domagalski, "Ordines minores," RAC 26 (Stuttgart: Anton Hiersemann, 2015): 398-459; for the janitors: Juliette Day, "The Status and Role of Doorkeepers in the Early Medieval West," in Studies in Late Antiquity (forthcoming). A concise introduction and survey of sources on the presbyters in early Christianity can be found in Joseph G. Mueller, "Presbyter," RAC 28 (Stuttgart: Anton Hiersemann, 2018): 86-112. 
8 subdeacons, 4 deaconesses, 3 lectors, 4 cantors, a janitor, 8 grave-diggers, and an unspecified cleric are attested in the former; 5 presbyters, 5 deacons, and an archdeacon in the latter. ${ }^{7}$ The problem is that the timespan of this evidence is too broad to make it possible to tell how many of these clerics were active at the same time. The second problem is that in most cases we can only very roughly assess the population of late-antique cities, towns, and villages. The third problem is that before the sixth century it is difficult to say what part of the population was Christian.

But some approximations are possible. They are based mostly on various lists or letters signed by groups of clerics from a specific city, town, or village, which, importantly, are usually well-dated. Admittedly, this does not resolve the problem with the assessment of the Christian population, but, as we will see, a rough estimation is sometimes sufficient; also we may be wrong when giving an absolute number of the inhabitants of a specific city, but we are less likely to err completely when trying to compare the population of different cities, using the same criteria.

\section{Rome}

Our best data come from Rome which is the only city in which we can see a changing number of presbyters in the course of a few centuries. The earliest piece of evidence, the famous mid-third century letter of Bishop Cornelius to his counterpart, Fabius of Antioch, is preserved by Eusebius. According to this letter, the Church of Rome had 46 presbyters, 7 deacons, 7 subdeacons, 42 acolytes, 52 exorcists, lectors, and janitors. ${ }^{8}$ How large was the population which this clergy served? When the letter was written the Christians were only a fraction of Rome's population. In Rodney Stark's model by 250 , the Christians constituted $1.9 \%$ of all the inhabitants of the Roman Empire; in the city of Rome the level of Christianization was almost certainly higher, but we cannot say how much higher. ${ }^{9}$ The

7 Sabine Hübner, Der Klerus in der Gesellschaft des Spätantiken Kleinasiens (Altertumswissenschaftliches Kolloquium 15; Stuttgart: Franz Steiner Verlag, 2005), 98. Similarly, 134 presbyters are attested in inscriptions from Lycaonia, but they date from the period from the second to the fifth century: Cilliers Breytenbach and Christiane Zimmermann, Early Christianity in Lycaonia and Adjacent Areas (Early Christianity in Asia Minor 2/Ancient Judaism and Early Christianity 101; Leiden: Brill, 2018), 605-606.

8 Eusebius, Historia ecclesiastica 6,43,11 (SC 41, 156 Bardy).

9 Rodney Stark, The Rise of Christianity: How the Obscure, Marginal Jesus Movement Became the Dominant Religious Force in the Western World in a Few Centuries (San Francisco: Harper Collins, 1997), 6-10. 
additional problem is that we do not know the total number of the inhabitants of Rome. If we assume that it was about a million, ${ }^{10}$ the number of Christians should fall within the lower tens of thousands. If they were 30,000 (which is rather an upper limit estimate) there would have been about 700 lay Christians for one presbyter, probably fewer.

Interestingly, in the following century the number of presbyters increased very little, if at all. Fourth-century Rome had over 20 tituli, quasi-parochial, largely autonomous churches. The Liber Pontificalis attributes the organization of 25 of them to Bishop Marcellus (ca. 305-306), and Peter Lampe remarks that this number corresponds quite well with 46 presbyters from the letter of Cornelius, assuming that each titulus had two presbyters. ${ }^{11}$ But in fact, the link between the tituli and Marcellus is highly problematic, and it is very uncertain whether any of them were based on earlier foundations from the pre-Constantinian period. Still, at the end of the fourth century, the anonymous author from Rome, most probably a presbyter, known as the Ambrosiaster, claims in his Commentary on the Epistles to Timothy that every (titular) church in Rome has two presbyters. ${ }^{12}$ That means that their total number did not change much in the city whose population was probably the same or similar as in the mid-third century, but now was becoming largely, and soon almost entirely, Christian. In ca. 400 about 50 presbyters apparently served a population of a few hundred thousand. If by then about half of the inhabitants of the city were Christian (which is not an excessively high estimate), ${ }^{13}$ there were over 10,000 laypersons for one presbyter, possibly fewer if the population of Rome dwindled, but more if the level of Christianization was

10 This is of course a long-debated issue. There are minimalists such as Glenn R. Storey, "The Population of Ancient Rome," Antiquity 71 (1997): 966-978, who thinks that Rome had roughly 450,000 inhabitants. For the sake of consistency and, more importantly, in order to make the data comparable, I will follow throughout this article, both for Rome and other cities, the assessments presented by Andrew Wilson, "City Sizes and Urbanization in the Roman Empire," in Settlement, Urbanization, and Population (ed. Alan Bowman and Andrew Wilson, Oxford: Oxford University Press, 2018), 161-195 (who estimates the number of inhabitants of Rome at one million).

11 Peter Lampe, From Paul to Valentinus. Christians at Rome in the First Two Centuries (Minneapolis: Fortress Press, 2003), 360-361.

12 Ambrosiaster, Commentarius in Pauli apostoli prima epistula ad Timotheum 3,13 (CSEL 81,3, 269,14-16 Vogels), see Presbyters in the Late Antique West database (henceforward PLAW) Evidence Record 2270 (Marta Szada).

13 We cannot measure the level of Christianization in Rome at that time, but in Egypt from which we have much better data, it is now assessed at $75 \%$ ca. 400, see Mark Depauw and Willy Clarysse, "How Christian was Fourth Century Egypt? Onomastic Perspectives on Conversion," VigChr 67 (2013): (407-435) 432. 
higher. Be that as it may, compared to the situation from the mid-third century (ca. 700:1) this ratio is enormously high.

This ratio, however, probably changed soon afterwards. As we shall see, while the number of the Roman tituli in the fourth and fifth centuries remained quite stable, the number of the presbyters in each of them grew. According to a petition of the Roman clergy preserved in the Collectio Avellana, in 418/419, when a schism divided the Church of Rome, about 70 presbyters supported Pope Boniface and "very few" (paucissimis) his rival Eulalius. ${ }^{14}$ This piece of information comes from the partisans of Boniface, so it may underestimate the number of the opponents; there were likely more of them than "very few," but this phrasing could not be absurd: the enemies would have had no difficulty in demonstrating this. Thus, any number around 80 seems possible as the whole body of the presbyters in Rome. This is almost twice as many as in the third century and probably in the time of the Ambrosiaster. In the meantime, the population of Rome after the sack by Alaric certainly decreased, but the percentage of Christians in it grew: it is difficult to say whether these 80 served the same number of Christians as a few decades earlier, but it could hardly be dramatically different.

New evidence comes from the late fifth century. 76 presbyters took part in the Roman synod of 487; a few years later 65 presbyters were present at the synod of $495 .^{15}$ The difference between those who attended both councils strongly suggests that some presbyters were absent. This is even more visible in the list of those who were present at the council of 499. This list is all the more interesting as, unlike the previous two, it gives the names of the tituli of the participants. ${ }^{16}$ Altogether 67 presbyters from 29 intramural churches signed the acts of the synod (although 73 were mentioned before as present). The number of presbyters from a single titulus varied from one to three. Nine tituli were represented by three presbyters, five by only one. The absence of some clerics is evident if we have in mind that already at the end of the fourth century every titulus should have had two presbyters. Before 499 this number certainly grew. If during the time of the synod all the tituli had had three presbyters (which is not certain), the total number of

14 Anicius Aurelius Symmachus, Collectio Avellana 17,2.4 (CSEL 35,1, 63,26; 64,15 Guenther), see PLAW Evidence Record 1339 (Marta Szada).

15 The acts of the synod of 487: Felix II, Epistula 13 (ed. Andreas Thiel, Epistulae Romanorum pontificum genuinae et quae ad eos scriptae sunt a S. Hilario usque ad Pelagium II 1 [Braunsberg: Peter, 1868], 259-260), see PLAW Evidence Record 660 (Stanisław Adamiak); synod of 495: Gelasius, Epistula 30 = Collectio Avellana 103,1-3 (CSEL 35,1, 474,1-475,11 G.), see PLAW Evidence Record 661 (Stanisław Adamiak).

16 Acta synodi Romani a.499 = Symmachus, Epistula 1 (MGH.AA 12, 401 and 410-415 Mommsen), see PLAW Evidence Record 662 (Stanisław Adamiak). 
the presbyterial positions in the city would have been 87-probably this number did not grow much since 418, but we have to remember that in this time the population of the city, after another sack in 455, must have dwindled.

The number of presbyters, on the other hand, was still to grow. A funerary inscription of a certain Florus, found at the cemetery of St Pancratius and dated to 521, says that the parents of the deceased bought for him a burial place from the four presbyters of the titulus of St Crisogonus. ${ }^{17}$ If other tituli had the same number of presbyters and if they were still 29 , as in 499, there could have been 116 titular presbyters in the city.

In the later part of the sixth century, the names of some tituli changed, but their number did not grow, a few may have disappeared. The synod of 595 gathered only 33 presbyters from 21 tituli, none represented by more than two presbyters. ${ }^{18}$ If the level of absenteeism at the synods did not rise dramatically, the number of presbyters must have fallen substantially, but apparently not proportionally to the general decrease in the population of the city, which after the Justinianic wars may have been reduced dramatically in comparison to its climax. If a population of 50,000-100,000 was served by a few dozen presbyters (if we assume that 21 tituli had again two presbyters each they would have been 42 in total), we would be dealing with the ratio of ca. 1,200-2,400 laypersons to one presbyter, obviously higher than in the third century (ca. 1:700) but much lower than in the late fourth (ca. 1:10,000).

Needless to say, all the calculations presented above concerned the clergy from the Roman tituli and took no account of either big intramural churches such as the Constantinian Basilica (Lateran) and Santa Maria Maggiore, or numerous suburban churches, among them Saint Peter's on the Vatican, Saint Paul's on the Via Ostiense and Saint Lawrence Outside the Walls. Federico Guidobaldi assessed the number of various ecclesiastical buildings in sixth-century Rome, including both the above-mentioned great basilicas and minor oratories and monastic chapels, at $130 .{ }^{19}$ The tituli amounted to fewer than 30. Thus, in order to make our counting sensible, we have to ask how many clerics, active at Rome, served in the remaining hundred. I think the answer is: very few. Admittedly, most monasteries probably had permanent clerical staff, but since their presbyters were hardly active in the city they are outside our interest. As for other churches, our evidence is not entirely clear.

17 ICVR II, 4279,1; CIL VI, 9994; ILCV, 1137 see Epigraphic Database Bari EDB40239.

18 Gregory the Great, Registrum epistularum 5,57a (MGH.Ep 1, 366,13-367,19 Ewald/Hartmann). 19 Federico Guidobaldi, "Spazio Urbano ed Organizzazione Ecclesiastica a Roma nel VI e VII Secolo," in Atti del XIII Congresso Internazionale di Archeologia Cristiana 2 (Vatican City: Pontificio Istituto di Archeologia Cristiana, 1998), (29-54) 44. 
In 416, Pope Innocent I, answering a question of Bishop Decentius of Gubbio, explained to him the Roman practice of sending Sunday fermentum, a particle of the consecrated bread, to all the tituli to mark the unity between their clergy and the bishop. But, Innocent continues, the fermentum is not to be sent to parishes (per paroecias),

because the sacraments should not be carried a long way, this is why we do not send them to the presbyters appointed to various coemeteria, and the presbyters have the right and permission to make them.

quia nec longe portanda sunt sacramenta, nec nos per coemeteria diversa constitutis presbyteris destinamus, et presbyteri eorum conficiendorum ius habeant atque licentiam. ${ }^{20}$

This suggests two things. First, that on Sunday there was no Eucharist within the city-walls except in tituli and the place where the bishop celebrated it. Second, that there were some places in the parochiae (this must refer to village churches outside Rome) and at the coemeteria which had presbyters appointed to them. ${ }^{21}$ We can leave the village churches aside as their clergy could hardly participate in the liturgical life of the city. More important are the presbyters at the coemeteria, the term which must refer to suburban martyrial churches with adjacent cemeteries. $^{22}$ The problem is that these presbyters are otherwise entirely absent from our evidence and there is much to suggest that the coemeteria were served by the clergy from the titular churches.

First, the non-titular presbyters never appear in the synodal subscriptions. The acts of councils named above were signed only by those who held posts at the tituli. Secondly, we cannot see any presbyter from the coemeteria in the epigraphic evidence either. In the corpus collected by Isabelle Mossong, no presbyter is linked with any church other than a titulus, whereas 13 inscriptions mention those from tituli. ${ }^{23}$ This absence is even more conspicuous considering that the epigraphic evidence from suburban churches shows that their construction and embellishment were often funded by titular presbyters-it is hardly imaginable that they

20 Innocent, Epistula 25,5,8 (PL 20:556b-557a), see PLAW Evidence Record 1718 (Stanisław Adamiak).

21 See Glen L. Thompson, “The Pax Constantiniana and the Roman Episcopate," in The Bishop of Rome in Late Antiquity (ed. Geoffrey D. Dunn, Burlington: Ashgate, 2015), (17-36) 34-35.

22 For the original meaning of this word see Éric Rebillard, Religion et Sépulture. L'Église, les Vivants et les Morts dans l'Antiquité Tardive (Civilisations et Sociétés 115; Paris: Éditions de l'École des Hautes Études en Sciences Sociales, 2003), 15-17.

23 Isabelle Mossong, Der Klerus des Spätantiken Italiens im Spiegel der Epigraphischen Zeugnisse: eine Soziohistorische Studie (Berlin: De Gruyter, forthcoming). 
paid for the churches of other clerics. ${ }^{24}$ Also, we can see that burial places in suburban cemeteries were sold by the presbyters from tituli, which would be strange if the cemeterial churches had their own staff. The inscription listing the four presbyters from the titulus of St Crisogonus mentions only a praepositus of the cemetery of St Pancratius, but nothing suggests that he was a presbyter. ${ }^{25}$ Thirdly, according to the Liber Pontificalis, which does not mention clergy from nontitular churches either, Pope Simplicius (468-483)

decided that presbyters should stay in weekly turns in the basilicas of St Peter the Apostle, St Paul the Apostle and St Lawrence Martyr, for the penitents and baptism; from region III at St Lawrence, from region I at St Paul, and from region VI or VII at St Peter.

Hic constituit ad sanctum Petrum apostolum et ad sanctum Paulum apostolum et ad sanctum Laurentium martyrem ebdomadas ut presbyteri manerent, propter penitentes et baptismum: regio III ad sanctum Laurentium, regio prima ad sanctum Paulum, regio VI vel septima ad sanctum Petrum. ${ }^{26}$

Thus, it was once again the clergy from the tituli who administered baptism and penance in the big suburban basilicas; and while we cannot be sure that this solution was indeed decreed by Simplicius, as the Liber Pontificalis often attributes later customs to the popes of old, it should have reflected the practice known to its early sixth-century author. In all, not only are the presbyters from the hundred non-titular churches completely imperceptible in our evidence, but also each niche which they should have taken seems to be filled by the titular clergy. What should be done with the testimony of Innocent? Perhaps the presbyters appointed to martyrial churches were an ephemeral group, existing only in the early fifth century, or the appointment was only temporary (like weekly duties in the basilicas). Be this as it may, the non-titular presbyters, if they ever existed, were hardly visible in the ranks of the Roman clergy.

It is also puzzling that we do not hear about the clergy from the Constantinian Basilica at the Lateran, the main episcopal church of Rome, and from the bishop's curia. But it is possible that even in the sixth century the pope still had only a limited clerical entourage. Charles Pietri suggests that the decision of Lucius (253-254) who supposedly

24 Julia Hillner, "Clerics, Property and Patronage: The Case of the Roman Titular Churches," Antiquité Tardive 14 (2006): (59-68) 66.

25 See above and also other inscription attesting a purchase of a tomb from two presbyters of St Crisogonus: ICVR N. S. II, 4312 = ILCV 1138 see EDB18453.

26 Liber Pontificalis 49,2 (ed. Louis Duchesne, Le Liber Pontificalis. Texte, Introduction et Commentaire 1 [Bibliothèque des Écoles Françaises d’Athènes et de Rome 1/École Française de Rome 3,1; Paris: E. Thorin, 1886], 249,4-7), see PLAW Evidence Record 542 (Stanisław Adamiak). 
laid down that two priests and three deacons should not leave the bishop, wherever he was, to be witnesses on the church's behalf,

Hic praecepit ut duo presbiteri et tres diaconi in omni loco episcopum non desererent propter testimonium ecclesiasticum,

in fact reflected the customs of the sixth century when this part of the Liber Pontificalis has been written. ${ }^{27}$ Probably no other presbyters were permanently affiliated with the Lateran, and even if they were this did not change the liturgical landscape of Rome; they would not have had an autonomous position, their ritual role would have been limited to assisting at the ceremonies celebrated by the bishop. The job of celebrating the Eucharist, baptising, administering penitence, and burying the dead was performed by the bishop himself and the presbyters from the tituli.

Let us take now a closer look at the changes in the number of this group. As we have seen, this number grows very slowly from the mid-third to the latefourth century (from 46 to no more than 50-60), reaches ca. 80 in the second decade of the fifth century, seems close to this number at the end of that century and almost certainly exceeds 100 (perhaps amounting to 110-120) at the beginning of the sixth century. At the end of that century it falls substantially to about 40. In terms of the ratio of the lay Christians per presbyter we can see a dramatic rise between the third and the fifth century (the presbyters became only a bit more numerous, while the lay population grew several times). In the fifth century the situation probably did not change much (the number of the presbyters became higher, the number of lay Christians is difficult to assess), in the sixth century the ratio fell as the number of the presbyters decreased much less than the lay population.

The relatively small decrease in their ranks in the sixth century is not strange, given the growing position of the Church in the city and especially its wealth. But the slow rise of the number of presbyters during the "little peace of the Church" and in almost two centuries which followed the end of the persecutions, that is in the period in which the Christian population of the city may have grown 20-30 times, calls for an explanation.

It is unlikely that fewer presbyters were needed because of a change in their cultic or teaching role. As we shall see, if anything, the contrary is true. We cannot see any type of presbyterial activity which would have disappeared in

27 Liber Pontificalis 23,3 (153,3-4 D.); see Charles Pietri, Roma Christiana. Recherches sur l'Église de Rome, son Organisation, sa Politique, son Idéologie de Miltiade à Sixte III (311-440) (Bibliothèque des Écoles Françaises d'Athènes et de Rome 124, Paris: De Boccard, 1976), 668-669. 
the fourth or fifth century. Why then did the number of the presbyters in Rome not keep pace with the growth of the number of the faithful? The answer probably lies in the material situation of the clergy. The tituli were above all not church buildings, but church endowments which supported both the maintenance of the infrastructure and the clergy. They were run by titular presbyters who financially, up to the end of the fifth century, were largely independent of the bishop. This only changed during the episcopacy of Symmachus (498-514). As Kristina Sessa convincingly argues, an important aspect of the Laurentian schism which divided the Church of Rome during his papacy, was a conflict over the financial management of the tituli, which Symmachus, quite successfully, tried to take over. ${ }^{28}$ The independence of the titular churches was based not only on their endowment or additional donations, but also on the fact that they were centres of pastoral and liturgical activity: they were obviously attended on Sunday for the Eucharist, but the archaeological traces of baptisteries show that it was the same with baptism. ${ }^{29}$ The offerings brought both to the altar and the baptismal font, even if not obligatory, made an important source of income for the clergy.

Now, as David Hunter shows in his article in this issue, at the end of the fourth century some Roman presbyters were anxious about their remuneration, and it is unlikely that this changed dramatically in the following century. In the times of the Ambrosiaster, the income of the staff of every titulus was divided among two presbyters and the lower clergy. Introducing another presbyter reduced the amount of work, but it also reduced the income of each presbyter by $1 / 3$. That was a serious problem, especially if these presbyters relied on church salary as their main or even only source of income, which most probably was the case at this time. I think then that it was the titular clergy who were reluctant to increase their number, just as they were reluctant to ordain outsiders to any but the lowest grades of hierarchy and were opposed to the swift promotion of those who gained the favour of the bishop. ${ }^{30}$ The situation changed, perhaps slowly, between the time of the Ambrosiaster and the end of the fifth century, since-as we have seen-in 499 at least some tituli were staffed by three presbyters. But then, at the

28 Kristina Sessa, The Formation of Papal Authority in Late Antique Italy: Roman Bishops and the Domestic Sphere (Cambridge: Cambridge University Press, 2012), 230-235.

29 Augusto Cosentino, "Il Battesimo a Roma: Edifici e Liturgia," in Ecclesiae Urbis. Atti del Congresso Internazionale di Studi sulle Chiese di Roma (IV-X Secolo) Roma, 4-10 Settembre 20001 (ed. Alessandra Guidobaldi and Federico Guidobaldi; Studi di Antichità Cristiana 59; Vatican City: Pontificio Istituto di archeologia cristiana, 2002), (109-142) 129-138.

30 Robert Wiśniewski, “The Last Shall Be Last: The Order of Precedence among Clergy in Late Antiquity,” Sacris Erudiri 58 (2019): (321-337) 332-337. 
beginning of the sixth century a new enlargement of the body of the presbyters must have taken place. This is attested by the inscription from 521, naming four presbyters of St Crisogonus. Interestingly, there is another piece of evidence suggesting that this time it was a swift enlargement that took place. According to the Liber Pontificalis, during 15 years of his episcopacy, Symmachus

performed four December and February ordinations in Rome, 92 presbyters, 16 deacons.

Hic fecit ordinationes IIII in urbe Roma per mens. decemb. et febr., presbiteros XCII, diaconos XVI. ${ }^{31}$

Admittedly, the numbers of ordinations given by the Liber Pontificalis are notoriously problematic, but those which come from the sixth century are consistent and plausible, and seem to be taken from the papal archives to which the authors of the Liber Pontificalis had access. ${ }^{32}$

Symmachus ordained by far more presbyters than any other pope between the fourth and the seventh century. And this certainly did not result from the lack of ordinations during the episcopacy of his predecessors, as Gelasius and Anastasius II (six years altogether) ordained 44 presbyters, well above the average of Late Antiquity. ${ }^{33}$ The closest to Symmachus' score was that of Leo I who made 81 presbyters, but his rule was longer (21 years). ${ }^{34}$ It seems then that at the beginning of the sixth century the number of the presbyters in Rome grew by leaps and bounds. That must have resulted from the decision of the bishop and most probably should be connected with the tightening of the control over the tituli, which, as Sessa shows, had serious financial consequences: The fourth presbyter in St Crisogonus, and probably many others like him, were forced upon the titular clergy by the pope. ${ }^{35}$

The situation in early sixth-century Rome shows us something important. If we think about the growing number of clerics in the society it is important to note that while in the long run the ratio certainly tipped in their favour, as Wood has recently emphasised, ${ }^{36}$ this growth could be discontinuous and the process was complex, with various interests and players. The interest of the average lay Christians, rich donors, presbyters, and bishops was not the same. We may suppose that the lay Christians wanted to have presbyters at hand, who would

31 Liber Pontificalis 53,12 (263,10-11 D.).

32 Peter A. B. Llewellyn, “The Roman Clergy during the Laurentian Schism (498-506): A Preliminary Analysis,” Ancient Society 8 (1977): (245-275) 247-248.

33 Liber Pontificalis 51,7 (255,16-17 D. for Gelasius) and 52,3 (258,6-7 D. for Athanasius).

34 Liber Pontificalis 47,9 (239,10-11 D.).

35 See note 17.

36 Wood, The Transformation (see note 3), 57-73. 
marry them, baptise their children, visit their sick, give them penance, and bury them when they died. But we have to remember that in fact we can say very little about the wishes of this group whose religious needs and behaviours are only rarely recorded in our evidence. ${ }^{37}$ And we also can say that the swift rise of the number of lay Christians in Rome in the latter third and the fourth century by no means resulted in the swelling of the ranks of the clergy. Initially, this number grew not so much in the function of pastoral needs as in close connection with the foundation of new tituli by rich donors, lay or clerical. ${ }^{38}$ But the building of a church was a pious act in itself and while it certainly mattered for the fifthcentury donors whether the shrine they had founded had any relics, it was not that important whether it was staffed or not by the clergy: that is why we can see so many churches in Rome which did not have permanent clerics. Only much later did the situation change and the clergy, and more specifically the presbyters, start to be essential for the pious foundations of those who thought seriously about their salvation: this change came when the Eucharist became the most important tool thanks to which the "not-so good" hoped to pass the gate of the Kingdom of Heaven. But while this phenomenon may not be as late as we often think, it hardly started before the sixth century. ${ }^{39}$ It is not by accident that in Peter Brown's The Ransom of the Soul, dealing specifically with the ways of paying off one's sins with money, the Eucharist is almost absent. ${ }^{40}$ Only with the growing role of the Mass for the dead did it become important not only to have a church built, but also to ensure the regular celebration of the Eucharist. ${ }^{41}$ Admittedly, the donors often wanted to have their presbyters cheap-as we can see in admonitions addressed to them, reminding them that the church has to be endowed sufficiently to support its clerics-but they still needed them. ${ }^{42}$ The donors then were largely behind the swelling of the numbers of the clergy, and particularly

37 Lisa K. Bailey, The Religious Worlds of the Laity in Late Antique Gaul (London: Bloomsbury, 2016), 8-18.

38 Hillner, “Clerics, Property and Patronage” (see note 24).

39 I am referring here to the yet unpublished research of Jerzy Szafranowski, working on the project Presbyters and Deacons in Monastic Communities in Late Antique Gaul. I am grateful to him for discussing with me this issue.

40 Peter Brown, The Ransom of the Soul. Afterlife and Wealth in Early Western Christianity (Cambridge: Harvard University Press, 2015).

41 Valerius of Bierzo, Ordo querimoniae 5 (ed. Consuelo M. Aherne, Valerio of Bierzo, an Ascetic of the Late Visigothic Period [Studies in Medieval History N.S. 11; Washington: The Catholic University of America Press, 1949], 81,9-83,14, see PLAW Evidence Record 779 (Marta Szada).

42 See e.g. Gregory the Great, Registrum epistularum 6,50 (CChr.SL 140, 423,1-12 Norberg), see PLAW Evidence Record 2313 (Jerzy Szafranowski) and a contemporary synodal canon: Concilium Toletanum a.597, Canon 2 (ed. José Vives, Concilios Visigóticos e Hispano-Romanos [Barcelona: 
the presbyters, who were the only clerics besides the bishops who were able to celebrate the holy mysteries.

The role of the bishops in the augmentation in the numbers of clergy was complex. On the one hand, they should have thought about the pastoral needs of their cities and dioceses. ${ }^{43}$ Also, a higher number of clerics may have been a way of enhancing prestige, and appointing supporters to presbyterial posts strengthened the position of a bishop whose rule was challenged. This was likely the case in the ordination of 92 presbyters during the pontificate of Symmachus.

But there was also the other side of this coin. The bishops had reasons to be concerned about new ecclesiastical foundations, and not only because they often found them underendowed. First of all, new churches, staffed with presbyters, particularly in the city, may have drawn the faithful away from the Eucharist and Baptism celebrated by the bishop, which obviously had a negative impact on his financial situation. That was a problem which needed rules to be fixed: At the end of the fifth century, Pope Gelasius, writing to an Italian bishop, explains that while people can be baptized in a church of their choice, the presbyter of that place should pay a cathedraticum to the bishop-the offerings brought to the font were to be divided. ${ }^{44}$ Secondly, private foundations, giving their clerics a fair degree of financial independence, made them difficult to control by the bishop. The bishops gathered at the seventh-century council of Chalon complain that those who hold these estates

contest with bishops and do not permit an archdeacon to punish clerics who serve in those oratories.

Episcopis contradicant et iam nec ipsus clericus, qui ad ipsa oraturia deserviunt, ab archidiacono cohercere permittant. ${ }^{45}$

Consejo Superior de Investigaciones Científicas, 1963], 156-157, see PLAW Evidence Record 655 (Marta Szada).

43 Gregory thought about other cities of Italy as well, see e. g. Gregory the Great, Registrum epistularum 1,15 (15,1-12 N.), see PLAW Evidence Record 2178 (Jerzy Szafranowski); and 2,35 (120,119 N.), see PLAW Evidence Record 2302 (Jerzy Szafranowski).

44 Gelasius, Epistulae fr. 20 (494-495 T.), see PLAW Evidence Record 2023 (Stanisław Adamiak). For a more detailed study on this topic see Dominic Moreau, "To Baptise in Late Antiquity-Not an Episcopal Prerogative. Some Remarks Inspired by the 'Scythian Case,'” Rivista di Archeologia Cristiana (forthcoming).

45 Concilium Cabilonense a.647-653, Canon 14 (CChr.SL 148a, 306,79-81 de Clercq), see PLAW Evidence Record 1618 (Jerzy Szafranowski). 
In all, bishops may have been driven by different and contradictory motives. Still, the process was impossible without their consent and collaboration because only they could legitimately ordain new presbyters in their dioceses.

\section{Other big cities}

We are more in the dark as to the number of presbyters in other major episcopal sees. In Alexandria, the position of the presbyters was unusually strong because at least up to the mid-third century they not only elected but also ordained the bishop. According to our sources, the most important of which is a fourth-century partly extant text known as the History of the Episcopate of Alexandria, the original presbyters in the number of twelve were ordained by Mark the Evangelist, the founder of the church in the city. ${ }^{46} \mathrm{~A}$ new bishop was to be always chosen from among them and after his ordination a new member of the presbyterial collegium was elected to keep their number as twelve. These twelve presbyters were to be supported by seven deacons. Both these numbers, with excellent New Testament justification, are obviously highly symbolic, but we should not reject them too hastily. In Rome, throughout Late Antiquity there were indeed seven deacons, and the history of the difficult conflict between them and the presbyters shows that this number was real. ${ }^{47}$ We cannot say where the Eucharist was celebrated in Alexandria in the pre-Constantinian era, but there is no reason to doubt that the bishop and twelve presbyters sufficed to meet the liturgical needs of the entire Christian community in that period. After the end of the persecution, this number grew, but apparently not dramatically. In 335, when Athanasius of Alexandria was summoned before the Council of Tyre, two groups of presbyters wrote to the gathered bishops to support his case: both letters are quoted by Athanasius in his Apology against the Arians. The first of them was signed by 16 presbyters and five deacons of Alexandria, the second by 15 presbyters and 15 deacons from the region of Mareotis. ${ }^{48} 16$ is a low number, but it is certainly not symbolic, and Athanasius did not have any interest in making this number

46 Ewa Wipszycka, The Alexandrian Church. People and Institutions (The Journal of Juristic Papyrology Supplements 25; Warsaw: The Raphael Taubenschlag Foundation, 2015), 43-60.

47 See David G. Hunter, "Rivalry between Presbyters and Deacons in the Roman Church: Three Notes on Ambrosiaster, Jerome, and the Boasting of the Roman Deacons, " VigChr 71 (2017): 495510.

48 Athanasius, Apologia contra Arianos 73,5 and 75,6 (ed. Hans-Georg Opitz, Athanasius Werke 2,1 [Berlin: De Gruyter, 1935], 153,3-24 and 155,1-31). 
lower than it actually was. He suggests that the entire clergy of the city have signed the letter, but as it lists only five, and not seven, deacons we cannot be sure of that; perhaps there were a few more presbyters in Alexandria. But there were hardly many more; otherwise the letter would show the weakness of the group which supported Athanasius and so be counterproductive. At that time Alexandria was still the second largest city of the empire, with the population possibly as high as 500,000, half of that of Rome. ${ }^{49}$ If we assume that the level of Christianization of both cities was similar (we cannot say if it differed), 16 (or shall we say 20) presbyters in Alexandria would correspond to about 32 (40) in Rome. As Rome had had then about 50 presbyters, this number is lower, but not much lower.

We cannot assess the total number of presbyters in Constantinople, but we have very interesting data from one specific church. In 535, the emperor Justinian issued the law putting an upper limit to the number of the clergy at the Great Church in the city: 525 clerics (60 presbyters, 100 deacons, 40 deaconesses, 90 sub-deacons, 110 lectors, 25 cantors, and 100 janitors). ${ }^{50}$ Admittedly, the Great Church was a big ecclesiastical complex consisting of Hagia Sophia and three other churches, but this number is still huge. Importantly, the law was issued because in reality at that time the number was even higher, and in consequence, the church was heavily in debt, since its endowment was not sufficient. Justinian wanted the reduction to be natural; the current clerics were to stay at their posts but the new ones were not to be ordained in the place of those who died until the required limit had been met. Most probably this never happened. In 612, the emperor Heraclius set a new limit: 600 clerics (80 presbyters, 150 deacons, 40 deaconesses, 70 sub-deacons, 160 lectors, 25 cantors, 75 janitors). A separate limit of 74 clerics (12 presbyters, 18 deacons, 6 deaconesses, 8 sub-deacons, 20 lectors, 4 cantors, 6 janitors) was set for the Blachernae. ${ }^{51}$ We cannot say how many more presbyters there were in other churches of Constantinople, so there is no point in trying to put these numbers against the population of the city (probably ca. 500,000 before the plague). But the very fact that the complex of four churches, admittedly very big and rich ones, is served by over 60 (and then over 80) presbyters, while the Blachernae by 12, suggests a much higher total number than in Rome, and a different model of organiza-

49 Wilson, "City Sizes” (see note 10), 185-187.

50 Justinian, Novella 3,1,1 (ed. Rudolf Schöll and Wilhelm Kroll, Corpus legis civilis 3 [Berlin: Weidmann, 1895], 21,4-20).

51 Heraclius, Novella 1 (ed. Joannis Konidaris, Fontes Minores 5 [Forschungen zur Byzantinischen Rechtsgeschichte 8; Frankfurt: Löwenklau-Gesellschaft, 1982], 62,1-73,125). 
tion: in Rome in the sixth century we still cannot see a permanent staff of the great basilicas. Also, it is worth noting that while in Rome, in a later part of the sixth century, the number of presbyters was substantially reduced, in the Great Church of Constantinople it rose by $1 / 3$, in the period which certainly saw a very substantial decline in the population of both cities. ${ }^{52}$

We have little data to assess the number of presbyters and other clerics in lateantique Carthage, the second biggest city in the West after Rome with a population perhaps amounting to $300,000 .^{53}$ But we have a good starting point, as we know what the situation looked like in the mid-third century, when Cornelius, writing his letter to Fabian, mentioned 46 presbyters in Rome. ${ }^{54}$ About the same time, in 251, Cyprian, bishop of Carthage, then hiding from the persecution, was on the brink of losing control over his church and had to face the rebellion of a part of its clergy. In one of his letters he lists the presbyters who either support his case (they are three) or challenge his authority (they are five).$^{55}$ It seems that there were no others, and so Carthage had 8 presbyters in the very same year when Rome had 46. This was about half the number in relation to the entire population of the city, but considering that Christianity started to develop in Africa well over a century later than in Rome, the community of the former was probably relatively smaller than that of the latter. Sadly, we have virtually no numbers for a later period. Thanks to the writings of Augustine and some other literary texts we know a number of churches in Carthage. Lilianne Ennabli has listed 26 of them known from textual sources and 11 (six intramural and five cemeterial) attested by archaeological evidence, not counting chapels, oratories etc. ${ }^{56}$ But, as the example of Rome shows us, this cannot be easily converted into the number of clerics. At the end of the fifth century, in the 480s, we learn from Victor of Vita that when the toughest period of the persecution of Huneric started, there were still about 500 clerics at Carthage, including young boys serving as lectors; all of

52 Cyril Mango, Le Développement Urbain de Constantinople (IVe-VIIe siècles) (Centre de Recherche d'Histoire et Civilisation de Byzance, Monographies 2; Paris: De Boccard, 1985), 51-62, supposes that it fell to ca. 40,000. Jean Durliat, De la Ville Antique à la Ville Byzantine. Le Problème des Subsistances (Collection de l'École Française de Rome 136; Rome: École Française de Rome, 1990), 273-275 vaguely agrees.

53 Wilson, “City Sizes” (see note 10), 184.

54 See above, page 6.

55 Cyprian, Epistulae 43,1,1 and 43,3,2 (CChr.SL 3b, 200,3-11 and 203,45-59 Diercks), see PLAW Evidence Record 1261 (Stanisław Adamiak).

56 Lilianne Ennabli and André Mandouze, Carthage, une Métropole Chrétienne du IVe à la Fin du VIIe Siècle (Études d'Antiquités Africaines; Paris: CNRS Éditions, 1997), 60-61. 
them were then sent to exile. ${ }^{57}$ Victor was well informed about the situation in Carthage as he most probably was a local presbyter and one of the exiled, but this number needs to be taken with a pinch of salt as he was also interested in making the total number of those who suffered from the persecution as high as possible. Also, the number he gives does not tell us much about the presbyters; there was no fixed ratio between the middle and lower clergy. If we used the roughly contemporary ratio from the Great Church in Constantinople (among 525 clerics, also including lectors, there were 60 presbyters, that is over $11 \%$ of the total) Carthage would have had then about the same number of presbyters, which sounds probable but cannot be proven. ${ }^{58}$ It is worth remembering that in Rome there were probably over 80 presbyters at the end of the fifth century. Considering that the population of Rome was then most probably still much larger than that of Carthage it would be tempting to say that the ratio of the lay Christians to presbyters in the latter city was slightly higher, even after fifty years of Vandalic rule.

\section{Middle-size cities}

In 303, three (or possibly four) presbyters in Cirta, in North Africa, were present, together with Bishop Paul, two deacons, four subdeacons and over six fossores, when a commission carried an inventory of the church property at the beginning of the Diocletianic persecution. ${ }^{59}$ This does not give us much, since not only it is difficult to assess the level of Cirta's Christianization in this period, but also we cannot say whether the entire clergy appeared before the commission. Still, we can say that even if it was the case, and if there were only three presbyters in the city (and not four), their number in relation to the entire population, estimated as ca. 30,000, was at least about twice as high as it was in Rome. ${ }^{60}$

57 Victor of Vita, Historia persecutionis 3,34 (CSEL 7, 89,3-7 Petschenig).

58 According to Eusebius (see note 8), in Rome in the mid-third century there were 154 clerics (also including lectors), and 46 presbyters among them (30\% of the total). Carthage possibly had seven deacons, just as Rome, but this assumption is based only of the fact that both cities probably had seven ecclesiastical regions (in Carthage only six are identified: Anna Leone, Changing Townscapes in North Africa from Late Antiquity to the Arab Conquest (Munera 28; Bari: Edipuglia, 2007), 97-106.

59 Gesta apud Zenophilum = Augustine, Contra Cresconium 3,29,33 (CSEL 52, 440,4-9 Petschenig). In one case we cannot say whether we are dealing with one presbyter with a double name, or with two presbyters.

60 Wilson, “City Sizes” (see note 10), 184. 
A better approximation can be got for Hippo Regius. In 426, when Augustine named his successor on the episcopal throne, seven local presbyters were present. ${ }^{61}$ Hippo was a middle size city. If its population did not pass 10,000-12,000, which is rather unlikely, and if half of it was Catholic (we cannot assume that all former Donatists turned into Catholics and the pagans disappeared altogether) there were fewer, possibly many fewer, than 1000 people per presbyter. ${ }^{62}$

In the mid-fifth century, Bishop Ibas of Edessa, when defending his faith at the council of Chalcedon, assessed the number of his clerics, which he did not remember exactly, at just about 200 or even more. ${ }^{63}$ As he wanted to show how few were those who brought an accusation against him (they were four presbyters) in comparison with the rest of his clergy, 200 is hardly an underestimated number; but as the presbyters who brought a plaint were present at the council, Ibas could not really exaggerate it either. Thus, 200 must be an actual, if approximative, number of the clerics in Edessa. Ibas does not say how many presbyters he had, and when Maras, one of the accusers, was asked how many of them were present at the meeting of the entire clergy in Edessa at which Ibas had allegedly pronounced a heretical statement, his answer was, most disappointingly: "I don't know." ${ }^{64}$ Fortunately, later on, Ibas presented the letter of the clergy supporting him, which gives us the number that we want. The letter was signed by 14 presbyters, 37 deacons, 13 subdeacons, and 1 lector. ${ }^{65}$ Besides 14 supporters and 4 accusers of Ibas there may have been other presbyters in Edessa, but it is unlikely they were numerous. Another member of the clergy present at the council says that before an earlier synod one presbyter refused to sign a different letter supporting Ibas and the bishop made him regret it; the clergy in Edessa was evidently not in a position to stay neutral. ${ }^{66}$ Interestingly, the ratio of the presbyters to the total number of clergy in Edessa (18, perhaps 20 presbyters to 200) is quite similar to that in the Great Church of Constantinople (11\%).

A slightly lower number of presbyters can be found a few decades later in Ravenna. Due to a conflict between Bishop Ecclesius and a part of his clergy, in the late 520s, 10 presbyters from the city (together with 12 deacons, 5 subdeacons,

61 Augustine, Epistula 213,1 (CSEL 57, 372,13-373,5 Goldbacher), see PLAW Evidence Record 509 (Stanisław Adamiak).

62 Wilson, “City Sizes” (see note 10), 184 (Hippo's surface was ca. 60 ha).

63 Concilium Chalcedonense a.451, Actio 11,92 (ACO ser. I 2,1,3 p.27[386],32-33 Schwartz).

64 Concilium Chalcedonense a.451, Actio 11,103-104 (ACO ser. I 2,1,3 p.29[388],5-7 S.): Oi

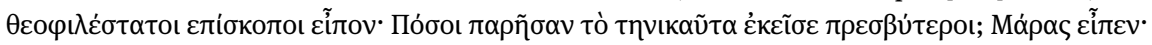

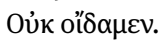

65 Concilium Chalcedonense a.451, Actio 11,141 (ACO ser. I 2,1,3 p.35[394],24-37[396],37 S.). 66 Concilium Chalcedonense a.451, Actio 11,106 (ACO ser. I 2,1,3 p.29[388],10-20 S.). 
12 acolytes, 12 lectors, 3 defensores, 4 cantors, 2 superintendents of stores and 2 deans) travelled to Rome, either to accuse the bishop or support his case. ${ }^{67}$ We cannot say how many more remained in the city. Agnellus to whom we owe this story suggests that Ravenna was emptied by the (Nicene) clergy, but this could not be really the case; the city could not possibly be left without any pastoral care. Ravenna's population hardly exceeded 10,000. By then it must have been almost entirely Christian, but partly Homoian; the number of the lay people for one Catholic presbyter was then certainly lower than in Hippo a century earlier. ${ }^{68}$ But we must remember that Ravenna is a specific case because as a centre of Roman and then Ostrogothic power it attracted ecclesiastical foundations far more numerous than was necessary for its limited size and population.

Almost in the same years, another group of presbyters were in conflict with their bishop, once again in the eastern Mediterranean. In 519, in the city of Apamea, which had a population of ca. 30,000, 20 presbyters signed a complaint against their metropolitan and the patriarch of Antioch. ${ }^{69}$ If these were all the presbyters of the city (we do not hear about others), the ratio of the lay to presbyters was higher than in Hippo; if not, it might be similar.

A higher number of clerics is attested in a later part of the sixth century in Auxerre in central Gaul. 34 presbyters and 7 abbots (who may have been presbyters as well) signed the acts of the diocesan synod which was held between 561 and $605 .{ }^{70}$ Auxerre was by no means a big city. ${ }^{71}$ It could hardly be as large as Hippo and so the number of the presbyters seems very high. But these presbyters, whose churches are not listed in the acts, certainly came from the entire diocese. If we remember this, their number becomes less shocking. In his article in this issue, J. Patout Burns compiled a list of about 20 presbyters from the countryside

67 Agnellus, Liber Pontificalis ecclesiae Ravennatis 60 (CChr.CM 199, 230,173-186 Deliyannis). 68 Salvatore Cosentino, "L’Approvvigionamento Annonario di Ravenna dal V all'VIII Secolo: L'Organizzazione e i Riflessi Socio-Economici,” in Ravenna: Da Capitale Imperiale a Capitale Esarcale 1 (Spoleto: Fondazione Centro Italiano di Studi sull'Alto Medioevo, 2005), (405-434) 411-412.

69 Epistula synodi episcoporum secundae Syriae (a.519) cum variis documentis (ACO ser. 1,3, p.92,20-31 Schwartz), see Frédéric Alpi, La Route Royale. Sévère d'Antioche et les Églises d'Orient (512-518) 2: Sources et Documents (Bibliothèque Archéologique et Historique 188; Beirut: Institut français du Proche-Orient, 2009), 98. For the population of Apamea see Wilson, “City Sizes” (see note 10), 190.

70 Synodus Autissiodorensis (CChr.SL 148a, 271,136-272,181 de Clercq), see PLAW Evidence Record 1563 (one presbyter was represented by a deacon).

71 Jean-Louis Voisin, “Auxerre gallo-romaine,” in Carte Archéologique de la Gaule. L'Yonne 89,1 (ed. Jean-Paul Delor; Paris: Académie des inscriptions et belles-lettres, 2002), 170-178. 
around Hippo, known from the correspondence of Augustine. ${ }^{72}$ If we add those to the seven presbyters of the city itself and remember about those whom Augustine simply did not have occasion to name, the total remains lower, but not dramatically lower from the list of those who were present at the council of Auxerre.

In all, the middle-size and large but not really big cities could have up to two dozen presbyters. This number probably tended to grow. The churches that we can see in the sixth century seem better staffed than those in the fifth-century evidence, but as we simply do not have data to compare, we can hardly observe this growth for any specific place. What we can observe is that in these cities the ratio of the laypersons to presbyters was substantially lower than in Rome, Constantinople, Alexandria, and Carthage. In consequence, the presbyters from Cirta, Hippo, Edessa, Ravenna, and Apamea must have been on average less busy in their clerical jobs than their colleagues from big metropolises.

\section{Countryside}

The presbyters from the countryside are usually much less visible in our evidence than the urban clergy. We know very little about theological discussions, ecclesiastical politics, and church ceremonies outside the city walls. But village priests are not entirely absent from our sources and there is one region, Egypt, in which we actually can see them better than their colleagues from big and famous Alexandria, one of the most important centres of late-antique Christendom.

We know village priests from the Nile Valley thanks to letters, petitions, accounts, and other types of documents preserved in papyri. Some of them simply enumerate local presbyters and deacons, others mention only a single church-office holder but are preserved as parts of large papyri archives which make it possible to reconstruct the list of the local clerics, mentioned in different documents. One such archive, consisting of the correspondence of the non-Chalcedonian (miaphysite) Bishop Abraham of Hermonthis, shows us a large village of Jeme (modern Luxor) in the Thebaid. Renate Dekker who was looking for clerics in Abraham's letters found six presbyters at the end of the sixth century. The same evidence mentions only one presbyter in the first decade of the seventh century but 13 in the years $610-619 .{ }^{73}$ Admittedly, it is possible

72 J. Patout Burns, "Presbyters Serving as Pastors in Roman Africa," in this issue.

73 Renate Dekker, Episcopal Networks and Authority in Late Antique Egypt. Bishops of the Theban Region at Work (dissertation; Orientalia Lovaniensia Analecta 264; Leiden: Peeters, 2017), 165-170 and 337-338. 
that not all of them were serving at the same time (the last set contains two archpresbyters, there was almost certainly only one at a time), but it is unlikely that during ten years many clerics died and were replaced. This suggests that there were about a dozen presbyters in Jeme, who served in at least four churches. This number is really large if put against the population of the village. On the basis of the well-preserved archaeological evidence (Jeme was abandoned in the eighth century, and before it was destroyed in the twentieth century it had been possible to measure its surface and even count houses) its population is assessed at 1,000-2,000 and some of its inhabitants were Chalcedonian. ${ }^{74} \mathrm{Granted}$, the presbyters of Jeme possibly also served the vicinity of the village, but it still means that in this region there was one presbyter for 200-300 people, and quite possibly even fewer.

Jeme was not exceptional in the Nile Valley. Even more interesting numbers come from Aphrodito (modern Kom Ishqaw), another town-size village, but substantially bigger than Jeme. ${ }^{75}$ We know Aphrodito particularly well thanks to a rich sixth-century dossier known as the Dioscorus archive, consisting of 680 contracts, petitions, complaints, accounts, letters, receipts, and poems. ${ }^{76}$ This dossier is full of presbyters, very numerous but not easy to count. They appear in various documents, and we cannot always tell whether they were active at the same time or not. Also, some of them owned a piece of land in Aphrodito but their church is not named and could be in a different village, other churches are named but even so we cannot be sure whether they were in Aphrodito. But at least two documents have impressive lists we can build upon. One of them is a petition against the local magistrate, pagarchos, addressed to the empress Theodora, written not later than 547 in the name of the inhabitants of the village. The petition is signed by ten presbyters associated with ten different churches in Aphrodito. ${ }^{77}$ These were not all of the churches in the village; there were at least two more and at least one of them, the church of Pinoution, certainly had its own presbyter. ${ }^{78}$ On the basis of this document we cannot say whether any of these churches had more than one presbyter, but the example of Jeme shows that it could be the case, and

74 Terry G. Wilfong, Women of Jeme: Lives in a Coptic Town in Late Antique Egypt (New Texts from Ancient Cultures; Ann Arbor: The University of Michigan Press, 2002), 12-13.

75 This paragraph is based on the evidence provided by Joanna Wegner to whom I am very grateful for sharing with me her finds which will be published in a forthcoming study on the clergy of Aphrodito.

76 See Giovanni Ruffini, Life in an Egyptian Village in Late Antiquity. Aphrodito Before and After the Islamic Conquest (Cambridge: Cambridge University Press, 2018), 8-9.

77 P. Cair. Masp. 3,67283, see Trismegistos TM 18420.

78 P. Cair. Masp. 3,67328 (A. D. 521), see Trismegistos TM 18453. 
another document from Aphrodito suggests that it was. In the tax register established in 525, we find the names of 36 presbyters, although it has to be said that some of them may have held the office elsewhere and others may have been dead when this document was made. ${ }^{79}$ This number, apparently exceeding twice that of the presbyters in the early fourth-century Alexandria, is enormous. Of course, we have to remember that Aphrodito was a very big village, even for Egypt. Its population is estimated at 7,000, not much less than that of such cities as Hippo or Ravenna, and most probably more than Auxerre. ${ }^{80}$ Thus, in Aphrodito the ratio we are interested in may have been similar to that we have seen in Jeme: 200, perhaps 300 persons for one presbyter.

No dossier of this kind can be found outside the Nile Valley, but in Anatolia numerous presbyters from the countryside are attested by epigraphic evidence. Admittedly, they appear most frequently in funeral inscriptions usually naming only one of them, which does not make counting possible. Luckily, this is not always the case, as sometimes we can see clerical families in which one presbyter is buried by his kin holding the same office, thus showing that there were at least two presbyters in the same church. A set of good examples comes from villages in the territory of Laodikeia Katakekaumene (Combusta) in Lycaonia. ${ }^{81}$ An inscription from this region, dated to the late fourth century, found in the village Atlant,, was composed by a certain Alexander for his brother Kosmion, both of whom were presbyters. ${ }^{82}$ Another inscription, from Gözlu in the same region, names three presbyters, most probably from two generations of the same family. ${ }^{83}$ In modern Kınık, a late-antique inscription, whose exact dating is unknown, shows us a certain Aurelius Phermios and his two sons, all three presbyters, who built a tomb for their family member. ${ }^{84}$ In Sarayönü, Aurelia Matrona, together with her sons, one of whom was a presbyter, commissioned a funerary inscription for her husband, the presbyter Alexander, and another presbyter, Mark. ${ }^{85}$ And these are

79 P. Aphrod. Reg. = P. Flor. 3,297 (A. D. 525), see Trismegistos TM 19352.

80 Constantin Zuckerman, Du Village à l'Empire: Autour du Registre Fiscal d'Aphroditô (525/526) (Monographies/Centre de Recherche d'Histoire et Civilisation de Byzance 16 ; Paris: Association des Amis du Centre d’Histoire et Civilisation de Byzance, 2004), 233.

81 See Breytenbach and Zimmermann, Early Christianity in Lycaonia (see note 7), 239-302. All the epigraphic evidence named in this paragraph comes from this chapter.

82 Inscriptiones Christianae Graecae (ICG): A Digital Collection of Greek Early Christian Inscriptions from Asia Minor and Greece (Berlin: Edition Topoi, 2016), online at: http://repository.edition-topoi.org/collection/ICG (last access March 31st 2021), see Inscriptiones Christianae Graecae 23.

83 Inscriptiones Christianae Graecae 145 (probably $6^{\text {th }}$ or $7^{\text {th }}$ century).

84 Inscriptiones Christianae Graecae 253.

85 Inscriptiones Christianae Graecae 515 (this inscription cannot be dated with any precision). 
not all the examples of two or three presbyters who were members of the same family and served in the same village. ${ }^{86}$ We should not think that these small localities, with a population in the lower hundreds, really needed more than one presbyter: just as they hardly needed more than one blacksmith. Rather, we are dealing here with family businesses in which one or more members of the young generation were trained on the job.

The evidence from Latin North Africa shows us a number of presbyters in the countryside, but we see hardly more than one in a specific place. In this respect it is very interesting to analyse the roll call which took place at the council of Carthage in 411, a final confrontation between the Catholics and Donatists. On its first day, the identity of all the Catholic participants was to be confirmed by their Donatist counterparts, and then the roll call went the other way round. In some places only one side had a bishop, the other only a presbyter. A single presbyter is attested in 7 Catholic and 13 Donatist communities. ${ }^{87}$ These are all villages, towns, perhaps very little cities in either Africa Proconsularis or Numidia, most of them otherwise unattested. Of course, in several of them either Catholics or Donatists might have constituted a tiny minority which simply did not need more clerics, but the fact that among these twenty places none apparently had more than one presbyter strongly suggests that this was a norm in villages or towns which did not have bishops. Interestingly, even cities in which the community was run by the bishop might have had only one presbyter. At a council in 397, Aurelius of Carthage, who hosted the meeting, tried to persuade other bishops to allow him to ordain their presbyters as bishops for other cities. But one of the participants protested in the name of those bishops who had only a single presbyter. ${ }^{88}$ This

86 Inscriptiones Christianae Graecae 508 (Mohajir, late $4^{\text {th }}$ century): two sons bury their father, all three are apotactite presbyters); Inscriptiones Christianae Graecae 511 (Sarayönü, $5^{\text {th }}$-early $6^{\text {th }}$ century): three children of a presbyter, one of them a deaconess and another a presbyter, build a grave for themselves while still alive); see also Inscriptiones Christianae Graecae 71 and Inscriptiones Christianae Graecae 68.

87 Gesta Conlationis Carthaginiensis (SC 195, 726-862 Lancel). Catholic presbyters: Macomades (PLAW Evidence Record 1000), Lamiggia (Evidence Record 1001), Sufasar (Evidence Record 1003), Caesariana (Evidence Record 1004), Aquae (Evidence Record 1010), Cereminianu (Evidence Record 1012), Medianas Zabuniorum (Evidence Record 1111); Donatist presbyters: Usula (Evidence Record 925), Avensa (Evidence Record 944), Zuri and Nigrenses Maiores (Evidence Record 945), Turuzi (Evidence Record 967), Vegesela (Evidence Record 968), Canopi (Evidence Record 978), Megalopolis (Evidence Record 983), Uchi Maius (Evidence Record 992), Casae Calanae (Evidence Record 993), Trofimiana (Evidence Record 994), Giutsitana Salaria (Evidence Record 996), Mididi (Evidence Record 997); all records by Stanisław Adamiak.

88 Registri Ecclesiae Carthaginensis Excerpta, Canon 55 (CChr.SL 149, 191,312-192,352 Munier), see PLAW Evidence Record 278 (Stanisław Adamiak). 
might not have been an unusual situation; indeed it is also attested by Canon 6 of the Council of Serdica (343), refusing to raise to the rank of bishopric those towns or small cities in which one presbyter was enough. ${ }^{89}$ The same can be seen on Patout Burns' list of 19 extra-urban localities which were served by presbyters known from the correspondence of Augustine, to which I have already referred. ${ }^{90}$ The only exception was Fussala, a castellum formerly belonging to the diocese of Hippo, which Augustine decided to carve out of its territory and make a bishopric. A newly appointed bishop, Antoninus, quickly found himself in conflict with the local population and clergy. Augustine got involved, and his letters, written in the years 422-423, shed some light on the situation in Fussala. Letter 20* describes an episcopal tribunal over Antoninus during which a letter of presbyters (not listed) of Fussala, brought by a presbyter from the town, was read out. ${ }^{91}$ This suggests that the town had at least two presbyters, and perhaps even three, if the bearer of the letter should be counted separately. But we know that Antoninus himself ordained one presbyter who kept his side in the conflict and it is unlikely that he signed the letter. ${ }^{92}$ This raises the number of the presbyters in the castellum to minimum three (or four), an exceptionally high number if compared not only with all the places named above, but also with seven presbyters attested in Hippo. But Fussala was a peculiar town. ${ }^{93}$ It was taken over by the Catholics only after 411, and the clerics who denounced Antoninus were likely former Donatist presbyters. That is why Augustine ordained a bishop from outside and why the latter ordained his own presbyter. Thus, a normal number of local presbyters in such a place would be two rather than three or four. We cannot assess the population of the localities named in the acts of the council of 411. They were certainly not as large as villages in the Nile Valley, but as in most cases we do not even know where exactly they lay, the population of several hundred (partly Donatist and partly Catholic) is just a guess. The pattern according to which the presbyters were deployed in the countryside in Africa was quite similar to that in Anatolia and different than in Egypt, but how much the ratio of the laypersons to presby-

89 Concilium Serdicense a.343, Canon 6 (ed. Cuthbert H. Turner, Ecclesiae Occidentalis monumenta iuris antiquissima 1,2,3 [Oxford: Clarendon, 1930], 459,18-460,31), see PLAW Evidence Record 2252 (Marta Szada).

90 Burns, "Presbyters Serving as Pastors in Roman Africa," in this issue.

91 Augustine, Epistula 20^,13 (CSEL 88, 101,22-102,12 Divjak), see PLAW Evidence Record 412 (Stanisław Adamiak).

92 Augustine, Epistula 20*,5 (96,20-97,12 D.), see PLAW Evidence Record 400 (Stanisław Adamiak).

93 Neil McLynn, “Administrator: Augustine in His Diocese," in A Companion to Augustine (ed. Mark Vessey; Blackwell Companions to the Ancient World; Malden: Willey-Blackwell, 2012), (310-322) 318-321. 
ters in these regions differed is impossible to say. ${ }^{94}$ However, there is no doubt that in all the regions we are dealing with one presbyter served a community of a few hundred people, no more.

\section{Numbers and patterns of the economic life of the clergy}

The list set above shows that in the communities of the Roman world the ratio of the presbyters to lay population differed, but the difference followed a certain pattern. In most villages, dispersed throughout the Mediterranean, only one presbyter, sometimes with his son holding the same office, served a population in the lower hundreds. Interestingly in the case of big town-like villages in Egypt, with a few thousand inhabitants, this ratio remained similar: these villages had a dozen or two dozen presbyters.

In the cities the situation was different. In the smallest of them, which can be seen in Africa, the community may have been run by a bishop who had just one or a few presbyters. In middle-sized regional centres, Hippo, Ravenna, Apamea, and probably Auxerre, their number did not exceed twenty, with about a thousand lay Christians for one presbyter-many more than in the countryside.

In the very large metropolises, such as Edessa, Carthage, and the biggest of them, Alexandria, the presbyters were numerous, but only in two super-cities, Rome and Constantinople, can we reasonably argue that their number was higher than a hundred. In both of them the ranks of this group most probably surpassed this number at the beginning of the sixth century. Importantly, it seems that in the big cities the ratio of lay Christians to presbyters was much higher than in the regional centres, with as many as a few thousand inhabitants for one presbyter.

94 It is difficult to say what the situation looked like in Gaul. Neither Caesarius of Arles nor Gregory of Tours, both of whom mention village priests in their writings, suggest that more than one of them served in the same place. An inscription found in Briord, east of Lyon, mentions a certain Amatus, prior presbyter of Vézeronce, which implies that there were other presbyters, below him in the hierarchy: Françoise Descombes, ed., Recueil des inscriptions chrétiennes de la Gaule 15: Viennoise du Nord (Paris: Éditions du CNRS, 1985), 265,2-3, see PLAW Evidence Record 1850 (Jerzy Szafranowski). But this probably refers to the office of archpresbyter: the first presbyter of the vicus in which there were different churches, each of them probably run by a single presbyter, see Christine Delaplace, "Les Origines des Églises Rurales (Ve-VIe Siècles). À propos d'une Formule de Grégoire de Tours,” Histoire et Sociétés Rurales 18 (2002): 11-40, especially page 20, and Robert Godding, Prêtres en Gaul Mérovingienne (Brussels: Société des Bollandistes, 2001), 243-260. 
Interestingly, while we can see three roughly consistent patterns of the numerical relationship between the presbyters and lay Christians in big cities, middle-size cities, and in the villages, the number of deacons followed different rules. They were seven in Rome, probably also in Carthage and in early-fourthcentury Alexandria, but as Sozomen remarks in the fifth century, this was by no means a universal custom. ${ }^{95}$ In Hippo, they were fewer than the presbyters, but in the Great Church of Constantinople and in Edessa, they were about twice as numerous. In the countryside their number may have been even higher, but it was not always so. The deacons from Mareotis who signed the letter supporting Athanasius were equal in number to the presbyters. But on the lists preserved on papyri we can see churches in which the former by far outnumbered the latter. A seventh/eighth-century papyrus with a payroll of the clergy from the church of Saint Theodore in Hermopolis in Egypt lists one presbyter, five deacons, and one doorkeeper. ${ }^{96}$ It is difficult to find a consistent pattern behind all these numbers. The deacons were evidently needed in every community, but in the cities which had only seven of them they could not possibly assist at every celebration of the Eucharist. It is unlikely that their liturgical role was taken over by the subdeacons whom the canons normally present as belonging to the lower clergy who did not have direct access to the sacred mysteries. It is not easy to explain why the deacons were so numerous in several small communities. Perhaps, the diaconate, even more than presbyterate, was a way of honouring a respectable member of the community. But, interestingly, it was not necessarily a cheap way of doing this; the payroll of the church of St Theodore, mentioned above, sets the allowance of the deacons and the presbyter at the same level.

I will return shortly to the different ratios of lay Christians to presbyters, but first, let us take another look at how these numbers changed over time. Admittedly, only very rarely can we compare them for the same city, but there are two important exceptions: Rome and Constantinople. As for the latter, we know that the maximum number of the presbyters at the complex of Hagia Sophia, set at 60 in the time of Justinian, was raised to 80 less than a century later, by Heraclius. But these were the upper limits which the emperors tried to impose. The actual number was higher, yet we cannot say how much higher and whether it really

95 Sozomen, Historia ecclesiastica 7,19,3 (GCS.NF 4, 330,15-18 Bidez/Hansen).

96 P. Misc. I 124a (seventh/eighth century, unpublished). P. Iand. VIII 154, see TM 21152, from an unknown place mentions one arch-presbyter, one presbyter probably in a martyr's shrine, one archdeacon, two other deacons, one collector, one mesites (the functions of the last two are not fully clear), one martyrarios, an unspecified group of subdeacons, gravediggers, parabalani, lectors, psaltai and philoponoi, one janitor, and one muleteer. Both papyri are discussed by Wipszycka, The Alexandrian Church (see note 46), 202-205. 
changed in the course of the seventh century. Also, since, as Justinian says, the Great Church was particularly attractive for the clergy, this change does not have to reflect the general growth of their number in Constantinople. ${ }^{97}$ It is not impossible that the number of presbyters in other churches fell in the same period, following the decrease of the population.

The evidence from Rome gives us more to build upon. It had 46 presbyters in the mid-third century, and we can see this number growing only two centuries later. Then, during the episcopacy of Symmachus, it must have surpassed 100, to fall by half or even more in a later part of the sixth century. This evolution was only loosely connected with the growth or decrease of Christian population of the city. In 400, the number of laypersons per presbyter was many times higher than in 250 . Around 500, it was substantially lower than in 400. Around 600, in spite of the decrease of the absolute number of the presbyters, their number grew in relation to the entire population, possibly as much as fivefold.

Thus, while the fluctuation of the number of presbyters was probably not entirely unrelated to pastoral needs, the connection was not fast. This, however, does not mean that these needs were unmet. Because while the number of presbyters in the city remained the same, the number of presbyter-hours could grow or fall. The presbyters who ran the community or communities in the third-century Rome may have been part-time clerics who still practised a secular profession. As András Handl shows in his article, the stipend offered to a third-century community leader hardly sufficed to cover the costs of living, let alone support the family. But if the clerics had other jobs, that was not necessarily a major problem. ${ }^{98} \mathrm{At}$ the end of the fourth century, however, this solution was not possible anymore. When the Christian population of the city grew several times, about 50 part-time presbyters could have hardly satisfied its pastoral needs.

That is particularly important if we realise that the scope of the presbyterial activities grew rather than diminished in this period and we need to take a closer look at them to understand how busy the clergy were. At the end of the fourth century, Roman presbyters certainly celebrated the Eucharist and preached. Admittedly, as the Ambrosiaster says, in the city churches the Mass was said normally only once a week, but this was hardly a change in respect to an earlier period. ${ }^{99}$ And importantly, we can see a general tendency towards a more fre-

97 Justinian, Novella 3,1 proem. and 3,1,1, (18-21 S./K.).

98 András Handl, “From Slave to Bishop. Callixtus' Early Ecclesial Career and Mechanisms of Clerical Promotion," in this issue.

99 Ambrosiaster, Commentarius in Pauli apostoli prima epistula ad Timotheum 3,12-3,13 (268,17270,2 V.), PLAW Evidence Record 2270 (Marta Szada), see David G. Hunter, “Ambrosiaster and the Problem of Clerical Profit” in this issue. 
quent celebration. One reason for that was the development of the cult of saints with a growing number of feast days. In the mid-fourth century the Church of Rome observed Christmas and feasts of 22 local martyrs or groups of martyrs. ${ }^{100}$ In the Martyrologium Hieronymianum which shows the situation at a later, but difficult to date, period, these were over $130 .{ }^{101}$ It is also possible that ca. 400 , the number of Masses celebrated on each Sunday was higher than before, as it is hardly imaginable that at that period either 20 or 30 tituli could accommodate all the Christians of the city at once. Even if we assume that only half of the population was Christian and only every second Christian went to church on a given Sunday, that would make a crowd of about 250,000 people. Of course, some of them attended the Mass at the Lateran and others went to some intramural or suburban churches, but, as we have seen, these too were served by the presbyters from the tituli, about 50 of them altogether. It is difficult to measure the total capacity of the churches in Rome at that time, but even if the Eucharist was celebrated in the 50 biggest of them, they were not likely to accommodate that number of people. Even if we divided 250,000 by half, assuming that the population of the city was much smaller than one million or that the churchgoers made only $25 \%$ of all the Christians, we would still have a crowd that would be impossible to squeeze in 50 Roman churches. ${ }^{102}$ Thus, most probably, on Sunday some presbyters celebrated more than one Mass. That the Church of Rome had a practice of repeating the Eucharist, at least on a major feast, is clear from the letter of Leo I to Dioscorus of Alexandria. Leo says that on such occasions which bring together

\begin{abstract}
a larger congregation than usual, too great a crowd of the faithful is assembled for one basilica to hold them all at once, there should be no hesitation about repeating the oblation of the sacrifice.

cum solemnior quaeque festivitas conventum populi numerosioris indixerit, et ea fidelium multitudo convenerit, quam recipere basilica simul una non possit, sacrificii oblatio indubitanter iteretur. ${ }^{103}$
\end{abstract}

The number of lay Christians for one presbyter was even more important in the rituals which were administered to single persons, and not the entire community,

100 Depositio martirum (MGH.AA 9, 71,1-72,19 Mommsen).

101 Martyrologium Hieronymianum (ed. Giovanni Battista de Rossi and Louis Duchesne, Acta Sanctorum Novembris 2,1 [Brussels: Apud Socios Bollandianos, 1894]). See the relevant entries in the Cult of Saints in Late Antiquity database: http://csla.history.ox.ac.uk/.

102 Optatus, Contra Parmenianum 2,4,5 (SC 412, 248,27-37 Labrousse), tells about forty basilicas in Rome in the mid-fourth century, other churches must have been smaller; see Thompson, "The Pax Constantiniana" (see note 21), 25-26.

103 Leo I, Epistula 9,2 (PL 54:626c-627a), see PLAW Evidence Record 1667 (Stanisław Adamiak). 
such as baptisms, funerals, and weddings. It is difficult to say how many people died in Rome every year in normal circumstances, but in pre-modern societies for which we have the data, the mortality rate could vary from 1.5 to $3.5 \%{ }^{104}$ For a population of 500,000 people (still on the assumption that $50 \%$ inhabitants of Rome were Christian ca. 400), this would make 7,500 to 17,500 funerals per year (144 to 337 per week). Admittedly, we cannot say how many funerals were attended by a priest. According to Augustine, when his mother Monica was being buried in Ostia, the Eucharist was celebrated at her grave. ${ }^{105}$ But the evidence collected by Éric Rebillard shows that this was by no means an obligatory practice. ${ }^{106}$ Let us suppose, that every second funeral was assisted by a presbyter (72 to 168 per week). Were 50 presbyters enough to deal with this task? Attending one or two funerals per week was perfectly feasible, attending three was not impossible, four probably happened very rarely. But it was time-consuming. We cannot say how long the ceremony took, but just going to the cemetery, all of which were suburban, took time. The catacomb of St Pancratius, which I have mentioned above, is nearly $2 \mathrm{~km}$ from St Crisogonus, and it takes almost an hour to go there and back at a normal pace. Also, we have to remember that in some cases at least, the Eucharist was celebrated before the burial. In all, the funeral certainly took the entire morning or a large part of the afternoon (the Mass was not celebrated at afternoon funerals). Importantly, funerals could not be planned long in advance, so the presbyters had to be always ready for them. Also, many of those who felt they would die asked for penance; some sick wanted to be visited by a priest, some young people wanted their marriages to be blessed. All these practices are attested at Rome, although we cannot say how frequent they were. ${ }^{107}$ For 50 priests, dealing with all this was possible, but not easy to reconcile with other professional activity.

Thus, the professionalization of the clergy probably did not result so much from the limits imposed by the synodal regulations which indeed place some, but only some, spheres of economic activity out of the presbyters' reach. Rather,

104 Walter Scheidel, "Roman Age Structure: Evidence and Models," The Journal of Roman Studies 91 (2001): (1-26) 6-7.

105 Augustine, Confessiones 9,32 (CChr.SL 27, 151,43 Verheijen).

106 Rebillard, Religion et Sépulture (see note 22), 143-160.

107 Blessing marriages: Liber Pontificalis 34,8 (171,15-172,5 D.), see PLAW Evidence Record 484 (Stanisław Adamiak); administering penance: Leo I, Epistula 167,9 (PL 54:1206a), see PLAW Evidence Record 1816 (Marta Szada); see also a general outline of this practice in Kevin Uhalde, "Juridical Administration in the Church and Pastoral Care in Late Antiquity," in A New History of Penance (ed. Abigail Firey; Brill's Companions to the Christian Tradition 14; Leiden: Brill, 2008), 97-120 and Claudia Rapp, "Spiritual Guarantors at Penance, Baptism, and Ordination in the Late Antique East,” in Firey, A New History of Penance (see above), (121-148) 122-127. 
as Norman Underwood argues, it was the clerical stipend, turning the volunteers into professionals, that was the major catalyst of this process. ${ }^{108}$ But the change did not happen merely because clerics started to be paid for their job. The professionalization was also enforced by the very slow increase in the number of clerics in the cities, which in turn resulted from the reluctance of the current postholders to admit new ones. This reluctance is understandable as every new presbyter diminished the income of the old, based on the endowment. Interestingly, the process of professionalization must have made this reluctance even stronger. As Hunter shows, at the end of the fourth century, the presbyters in Rome were seriously worried about the amount of their clerical pay, because they had to rely on it to a much greater extent than their predecessors. ${ }^{109}$ They could not possibly be enthusiastic about enlargement of their ranks.

Of course, the number of presbyters did not freeze entirely, but the only essentially uncontroversial way in which it could grow was a new endowment, and even this may have led to the reduction of the income of the old guard as it reduced the number of offerings received by the presbyters from the church adjacent to the new foundation on the occasion of baptisms, funerals etc. The other way of increasing the number of clergy was an arbitrary decision of the bishop in whose hands was the power of ordination. The bishop may have been pushed to that by those who asked impatiently for promotion or who wanted to join the clergy without passing the low grades of the hierarchy. Importantly, some bishops may have been more tempted to comply than others, as new ordinations strengthened the group of their supporters. This was particularly important for those bishops whose election was contested and position uncertain. But at the same time this was a risky step as it antagonized the existing clergy. We can see both phenomena during the episcopacy of Symmachus.

Once the number of presbyters grew, it rarely decreased. Admittedly, in Rome after Symmachus it did fall substantially, but that happened in the period when possibly as much as $90 \%$ of the population of the city disappeared. By contrast, in Constantinople, at least in one church that we know about, the number of presbyters probably grew or at least remained unchanged in the same century, in spite of the problems that it caused, the efforts of the emperors, and the general decrease of the population.

In the smaller cities the pattern of clerical income may have differed as the number of laypersons in relation to the presbyters was evidently lower. Sadly,

108 Norman Underwood, The Professionalization of the Clergy in Late Antiquity (dissertation; Berkeley: University of California, 2018).

109 Hunter, "Ambrosiaster and the Problem of Clerical Profit," in this issue. 
Hippo, the only city whose clergy is presented to us with any detail as far as their material situation is concerned, was a particular case: all the members of the local clergy from the grade of the subdeacon were expected to get rid of their property and live in a monastic-like community with their bishop. But on closer inspection it turns out that even there some presbyters spent part of their time pursuing non-clerical economic activities. Admittedly, we do not see among them any craftsmen. But we do see a presbyter running a farm and another who apparently was engaged in long-distance trade. ${ }^{110}$

The pattern in the countryside was more complex. In general, one church was served by one presbyter or by one presbyterial family: a father and one or two sons. But while in most regions of the Roman world we can hardly see more than one church in the village, in Egypt this number was often higher and a dozen presbyters, or even two dozen and more, could have been found in one locality. Admittedly, we know about these presbyters thanks to specifically Egyptian evidence: letters, lists, and accounts preserved in papyri, which had little chance to survive in any other region. But most probably in Egypt the number of presbyters in a single village was really higher than elsewhere, as the villages of the Nile Valley were exceptionally large. Thus, it is not easy to say if the number of villagers for one presbyter in this region was lower than in Latin North Africa or Anatolia. It could have been. But there is no doubt that it was much lower in the villages than in the cities. In consequence, the presbyters in the sixth-century Aphrodito and seventhcentury Jeme had a load of ecclesiastical work far smaller not only than that in the big metropolises such as Alexandria, but also in the middle-size cities. They certainly could pursue other professions. Importantly, they also most probably needed to do so for economic reasons for their clerical income was not sufficient to support them. An alternative was to entrust several churches to a single presbyter and make him celebrate a few Masses in the week. This solution was employed in the seventh-century Iberian Peninsula. But as we know it only from admonitions reminding the presbyters that they are obliged to celebrate the Eucharist in each church under their supervision, it seems that this system did not work perfectly. ${ }^{111}$

110 See Augustine, Sermo 356,15 (ed. Cyrille Lambot, Sancti Aurelii Augustini Sermones selecti duodeviginti [Stromata Patristica et Mediaevalia 1, Utrecht: Spectrum, 1950], 142,16-143,1): the presbyter Barnabas is running a farm, see PLAW Evidence Record 872 (Stanisław Adamiak); Augustine, Epistula 7,1 (39,2-3 D.): the deacon Faustinus travels from North Africa to Gaul to buy a ship for the presbyter Heraclius, see PLAW Evidence Record 47 (Stanisław Adamiak).

111 Concilium Emeritense a.666, Canon 19 (ed. Vives, Concilios Visigóticos e Hispano-Romanos [see note 42], 338-339), see PLAW Evidence Record 850; Concilium Toletanum a.693, Canon 5 ( 502 V.), see PLAW Evidence Record 1052, and the Tomus of King Egica, preceding the acts of this council (484 V.), see PLAW Evidence Record 1049 (all records by Marta Szada). 
Admittedly, the ecclesiastical income of the presbyters was not based only on the offerings brought by the faithful. Thanks to the tax register from Aphrodito we know that the local churches owned there $3.7 \%$ of the registered village land. ${ }^{112}$ In Temseu Skodron, another village in Upper Egypt from which this type of document has survived, this percentage was much higher: the Holy Church (most probably local) paid $15.1 \%$ of the total taxes, and the Holy Martyrion together with its oikonomos another $5 \% .{ }^{113}$ We do not know what the situation looked like in Jeme, but under the Chalcedonian emperors the Miaphysite community which we can see in the correspondence of Abraham was certainly in a less comfortable financial situation. Obviously, the income from the estates belonging to the Church was not spent entirely on clerics. In Late Antiquity it was usually divided into three or four parts, not necessarily equal: for the bishop, for the clergy, for the poor, and for the maintenance of the church. ${ }^{114}$ How much did the cleric get? As Ewa Wipszycka has shown, the papyri which bear witness to the clerical pay (normally in grain) strongly suggest that the yearly allotment of a village presbyter hardly sufficed to feed him, not to mention his family. ${ }^{115}$ Admittedly, this allotment was supplemented by offerings (or payments) on the occasion of baptisms, burials etc., but in the communities in which one presbyter cared for 200-300 people their number was far too low to keep the clergy busy and sufficiently paid. In other words, these were not full-time clerics, and they not only could but also had to have other sources of income.

And there is no doubt that they did. Wipszycka was the first to demonstrate that this was a normal practice in Egypt. ${ }^{116}$ Since the publication of her book on

112 The land belonged to nine churches and a few oratories, but this was not the total of church estates in Aphrodito. About $2.6 \%$ of the land belonged to two monasteries from the city of Panopolis. Also, a portion of land in Aphrodito was classified as "urban property" and was registered as such in the cadastral document known as astika. Of this $38 \%$ this belonged to various church institutions (but not from Aphrodito). See Roger S. Bagnall, "Village Landholding at Aphrodito in Comparative Perspective," in Les Archives de Dioscore d'Aphrodité Cent Ans après leur Découverte: Histoire et Culture dans l'Égypte Byzantine (ed. Jean-Luc Fournet and Caroline Magdelaine; Études d'Archéologie et d'Histoire Ancienne. Collections de l'Université Marc Bloch-Strasbourg; Paris: De Boccard, 2008), (181-190) 184.

113 Bagnall, "Village Landholding at Aphrodito" (see note 112), 184.

114 See Ian Wood, “The Early Medieval West as Temple Society," Rivista Storica dell'Antichità 49 (2019): (117-144) 130-140.

115 Wipszycka, The Alexandrian Church (see note 46), 202-208.

116 Ewa Wipszycka, Les Ressources et les Activités Économiques des Églises en Égypte du IVe au VIII Siècle (Papyrologica Bruxellensia 10; Brussels: Fondation Égyptologique Reine Élisabeth, 1972), 154-173. 
the economic resources and activities of the church in Egypt, new papyrological evidence and new studies have shown us even better the extent of this phenomenon. First of all, in Egypt the clerics were busy farming. The tax register from Aphrodito is important not only because it lists the estates of the church and names the 36 presbyters, but also because it shows that they paid taxes from the land they possessed themselves. In other sources we can see presbyters pursuing all sorts of crafts: we find among them bakers, weavers, dyers, potters, blacksmiths, goldsmiths, saddlers, carpenters, camel-drivers, bankers, scribes and alike. ${ }^{117}$ Importantly, recent research, based largely on inscriptions, leaves no doubt that the practice was not limited to the Nile Valley. In Anatolia, we can also find presbyters who had a secular profession. ${ }^{118}$ Was this also the case for the West? We cannot answer this question with certainty. The epigraphic evidence very rarely tells us about presbyters having secular jobs in Italy, Spain, Gaul, or North Africa. But this may reflect a different (or simply less developed) epigraphic habit rather than a different model of maintenance. Latin literature does not tell us much about this kind of activity either. Gregory the Great mentions a presbyter Severus from the valley of Antrodoco, in central Italy, who was busy in his vineyard; later on, Valerius of Bierzo reminiscences how he and the presbyter Saturninus grew vegetables close to their village church in northern Spain. These testimonies are very few, but if we relied on narrative sources, we would not find many priests tilling the land in Egypt or Anatolia either. In Gregory and Valerius these stories are told only because they introduce an account of a miracle. ${ }^{119}$ Thus, the difference may lie in the evidence rather than in reality. This is what three canons of the collections known as Statuta Ecclesiae Antiqua seem to suggest:

117 Georg Schmelz, Kirchliche Amtsträger im Spätantiken Ägypten nach den Aussagen der Griechischen und Koptischen Papyri und Ostraka (Archiv für Papyrusforschung und Verwandte Gebiete/Beiheft 13; Munich: K. G. Saur, 2002), 203-254. See also Hanno Dockter, Klerikerkritik im Antiken Christentum (Göttingen: V\&R Unipress, 2013), 106-110.

118 For Asia Minor see Josef Keil and Adolf Wilhelm, eds., Monumenta Asiae minoris antiqua 3: Denkmäler aus dem Rauhen Kilikien (Manchester: Manchester University Press, 1931): ciderdealer (760), Romanos the banker and presbyter (676), priest and goldsmith (3.336)-all three collected by Underwood, The Professionalization (see note 108), 27 (note 126).

119 Gregory the Great, Dialogi 1,12,1-3 (SC 260, 112,1-114,40 de Vogüé), see PLAW Evidence Record 186 (Jerzy Szafranowski); Valerius of Bierzo, Ordo querimoniae 11 (141,10-140 A.), see PLAW Evidence Record 786 (Marta Szada). 
Canon 29 (LII): Clericus victum et vestimentum sibi artificiolo vel agricultura absque officii sui dumtaxat detrimento praeparet. ${ }^{120}$

Canon 45 (LIII): Omnes clerici qui ad operandum validi sunt, et artificiola et litteras discant. ${ }^{121}$ Canon 79 (LI): Clericus, quamlibet verbo Dei eruditus, artificio victum quaerat. ${ }^{122}$

This collection was compiled in Gaul close to the end of the fifth century, possibly by Gennadius of Marseille, but it uses the material whose origin can be only partly identified. We do not know what is the source of the canons quoted above. They are unique and we cannot exclude that they reflect the views of the compiler, and not those of any synod. Still, considering that the synodal canons forbid only very specific types of economic activity, such as selling slaves, lending money on interest or conducting business which requires long absence, we may suppose that the phenomenon was much more widespread in the West than our evidence makes it possible to see.

The different model of activity and income of the urban and village clerics must have widened the gap between the professional skills of the former and the latter. Obviously, already the starting point of the two groups was different, as the urban population was generally better educated and the priests in the cities were more likely to come from more affluent families. But the different amount of time spent on the clerical job probably put these groups even further apart. This, of course, does not necessarily mean that the village priests did not play an important social role in the life of their communities. But their role was different than that of urban presbyters. They spent less time performing rituals, but instead supported the petitions of the village, witnessed contracts, acted as mediators and arbiters in their communities. ${ }^{123}$

120 Concilia Galliae a.314-a.506, Canon 29 (CChr.SL 148 171,82-83 Munier; trans. Szafranowski]): "A cleric should provide for his nourishment and clothing by craft or agriculture as long as it does not cause any harm to his office,” see PLAW Evidence Record 1189 (Jerzy Szafranowski).

121 Concilia Galliae a.314-a.506, Canon 45 (173,115-116 M.; trans. Szafranowski): "All clerics who are able to work, should learn crafts as well as the letters," see PLAW Evidence Record 1197 (Jerzy Szafranowski).

122 Concilia Galliae a.314-a.506, Canon 79 (179,192-193 M.; trans. Szafranowski): "A cleric, no matter how skilled in the word of God, should provide for his nourishment by means of a craft," see PLAW Evidence Record 1215 (Jerzy Szafranowski).

123 For contracts in Aphrodito see Ruffini, Life in Egyptian Village (see note 76), 53. Mediation and arbitration: Marzena Wojtczak, "Audientia sacerdotalis? Remarks on the Legal Nature of Dispute Resolution by Ecclesiastics in Late Antiquity,” in this issue. 